\title{
Analysing the energy performance of secondary schools in N. Greece
}

\author{
Vagi F. ' , Dimoudi A. ${ }^{1,2, *}$ \\ ${ }^{1}$ Hellenic Open University, MSc 'Environmental Design of Cities and Buildings', Patras, Greece \\ ${ }^{2}$ Department of Environmental Engineering, Democritus University of Thrace, Xanthi, Greece \\ * Corresponding author: Tel./Fax: +30.25410.79.388, E-mail: adimoudi@env.duth.gr
}

\begin{abstract}
Aim of this paper is the analysis of the energy performance of secondary school buildings in North Greece and the investigation of proposals for their energy upgrade. The survey was carried out by monitoring the energy performance of 20 secondary school buildings in the prefecture of Evros in Thrace and by simulating representative school buildings. Energy data both for heating and electricity, together with other information concerning structural details and operational characteristics for a period of 5 years (2001-2005) were collected. The energy data for the secondary schools are presented and compared with data from other regions in Greece. The mean heating energy consumption of secondary school buildings in the prefecture is $70.6 \mathrm{kWh} / \mathrm{m}^{2}$, with insulated buildings performing with $27 \%$ less energy consumption than non-insulated buildings. Simulation of representative school buildings in this area suggests that measures for natural lighting, reduction of infiltration losses, controlled ventilation during the winter, shading and natural ventilation during summer and the effective functioning of heating and lighting system are the major priority for the school building stock. Especially in the 'old school buildings', this type of interventions are necessary not only for achieving energy efficiency but for obtaining thermal comfort conditions in their interior.
\end{abstract}

Keywords: Energy efficiency, Schools, Monitoring, Simulations

\section{Introduction}

The mean annual energy consumption of buildings in Greece is allocated as : $406.8 \mathrm{kWh} / \mathrm{m}^{2}$ in hospitals, $273 \mathrm{kWh} / \mathrm{m}^{2}$ in hotels, $187 \mathrm{kWh} / \mathrm{m}^{2}$ in offices, $152 \mathrm{kWh} / \mathrm{m}^{2}$ in commercial buildings and $93 \mathrm{kWh} / \mathrm{m}^{2}$ in schools [1]. Although the energy consumption in school buildings is lower than other building categories, the overall energy consumption at national level is considered high due to the big number of school units, and the fact that they mainly operate during the heating period - they operate about 9 months -, they are not equipped with cooling systems and the majority of energy is spent for heating. The inadequate energy design of existing buildings, their age ( $40.9 \%$ is older than 30 years), their initial design $(87.3 \%$ designed for schools), their location and proximity with disturbance sources (33.5\% with high traffic roads, $15.9 \%$ with manufacturing premises and polluting areas), lack of regular maintenance and refurbishment can lead to education spaces with low thermal, visual and noise comfort, at reduction of pupils educational perception and additionally, at considerable environmental implications as a result of the increased energy consumption [2].

School buildings, due to their specialized operational characteristics and their social/ educational character have special requirements for environmental design for heating, cooling, ventilation and daylighting of their buildings. Collection of reliable energy data can facilitate to creation of a $n$ ational data base that is useful to support reliable energy certification of school buildings and also to facilitate national energy policy measures to be taken. Aim of this paper is the analysis of the energy performance of secondary school buildings in North Greece and the investigation of proposals for their energy upgrade.

\section{Methodology}

\subsection{Energy Consumption in School Buildings}

All school units in Greece are equipped with heating systems (99.9\% during the school year 2003-04) and the majority has a central heating system (88.0\%). According to the opinion of 
the Master of the school units, a portion of $11.1 \%$ considered as inadequate the operation of the heating system and in only $1.5 \%$ there was lack of heating operation during the years 2003-04 [2]. The energy consumption of school units, irrespective of education level (primary, secondary) based on previous surveys carried out in school units around Greece is reported in table 1. School buildings in Greece consume electrical energy mainly for artificial lighting and during the lasts years, especially in secondary schools, for new technologies (e.g. PCs). The mean energy consumption for heating and electricity in school buildings in other European countries, based on da ta from EC (Energy, E. C, 2000) [7] and other literature sources $[8,9,10]$ are presented in table 2 :

Table 1. Mean annual energy consumption in school buildings in Greece

\begin{tabular}{|c|c|c|c|c|c|c|}
\hline $\begin{array}{c}\text { Region / } \\
\text { Climate zone }\end{array}$ & $\begin{array}{l}\text { Year of } \\
\text { research }\end{array}$ & $\begin{array}{c}\text { No of } \\
\text { buildings }\end{array}$ & \multicolumn{3}{|c|}{$\begin{array}{l}\text { Mean heating energy } \\
\qquad\left(\mathrm{kWh} / \mathrm{m}^{2}\right)\end{array}$} & $\begin{array}{c}\text { Mean electrical } \\
\text { energy } \\
\left(\mathrm{kWh} / \mathrm{m}^{2}\right)\end{array}$ \\
\hline All Greece [1] & 1993 & 238 & & 67 & $\begin{array}{c}\text { Difference } \\
40 \%\end{array}$ & 26 \\
\hline All Greece [3] & 2006 & 340 & & 68 & & 27 \\
\hline $\begin{array}{c}\text { Evros / C } \\
\text { Climate zone } \\
{[4]}\end{array}$ & $\begin{array}{l}2001- \\
2005\end{array}$ & \begin{tabular}{l}
\multicolumn{1}{c}{10} \\
primary \\
Schools
\end{tabular} & $\begin{array}{c}\text { No-insulated } \\
89.4\end{array}$ & $\begin{array}{c}72.8 \\
\text { Insulated } \\
56.65\end{array}$ & $\begin{array}{c}\text { Difference } \\
37 \%\end{array}$ & 8.65 \\
\hline $\begin{array}{c}\text { Grevena / D } \\
\text { Climate zone } \\
{[5]}\end{array}$ & 2004 & 9 & $\begin{array}{c}\text { No-insulated } \\
139\end{array}$ & $\begin{array}{c}123.31 \\
\text { Insulated } \\
115.38\end{array}$ & $\begin{array}{c}\text { Difference } \\
17 \%\end{array}$ & 14.31 \\
\hline $\begin{array}{c}\text { Kozani / D } \\
\text { Climate zone } \\
{[6]}\end{array}$ & $\begin{array}{l}2003- \\
2007\end{array}$ & $\begin{array}{c}11 \\
\text { nursery } \\
10 \text { primary }\end{array}$ & & $\begin{array}{l}135.9 \\
105.8\end{array}$ & & $\begin{array}{l}7.5 \\
9.3\end{array}$ \\
\hline
\end{tabular}

Table 2. Mean annual energy consumption in school buildings of the member states of the European Union $[7,8,9,10]$

\begin{tabular}{cccc}
\hline $\begin{array}{c}\text { Member States of the European } \\
\text { Union }\end{array}$ & $\begin{array}{c}\text { Heating energy } \\
\left(\mathrm{kWh} / \mathrm{m}^{2} / \text { year }\right)\end{array}$ & $\begin{array}{c}\text { Electrical energy } \\
\left(\mathrm{kWh} / \mathrm{m}^{2} / \text { year }\right)\end{array}$ & $\begin{array}{c}\text { Mean annual } \\
\left(\mathrm{kWh} / \mathrm{m}^{2} / \text { year }\right)\end{array}$ \\
\hline $\begin{array}{c}\text { England (Mean value) } \\
\text { Secondary school (Gateshead) } \\
\text { Denmark (Skive) }\end{array}$ & $137-189$ & $20-27$ & \\
Primary school & 177 & & \\
Sweden (Karlskrona) & $170-175$ & & \\
Secondary school & 210 & & \\
Portugal (Agueda/Crato) & & & 96 \\
Secondary school & $64 / 67$ & & 110 \\
Ireland [8] & & & 192 \\
Italy [9] & & & \\
Slovenia [10] & & & \\
\hline
\end{tabular}

\section{Energy monitoring of secondary school units in the prefecture of Evros}

The energy monitoring survey was carried out in 20 secondary school units out of 45 in the prefecture of Evros (NE Greece) covering 10 Junior High Schools, that is the $42 \%$ of corresponding units in the prefecture and 10 High Schools, corresponding at $48 \%$ of the 
majority of high schools in the prefecture. The 5 out of the $10 \mathrm{j}$ unior high schools were located at the municipality of Alexandroupolis (the capital of the prefecture) thus, corresponding at $83 \%$ of the units in the municipality. The 8 out of 10 high schools were also located at the municipality of Alexandroupolis, covering the $63 \%$ of high schools in the municipality. During the survey, energy data for 5 years were collected (2001-2005), both for heating and electricity, together with other information concerning structural details and operational characteristics (e.g. no of pupils, heating system operation schedule, etc).

Table 3: Total mean annual energy consumption in 10 junior high schools of Evros Prefecture during the period 2001-05

\begin{tabular}{|c|c|c|c|c|c|c|c|c|}
\hline \multirow[b]{2}{*}{ No } & \multirow[b]{2}{*}{$\begin{array}{l}\text { Construct } \\
\text { ion year }\end{array}$} & \multirow[b]{2}{*}{$\begin{array}{l}\text { Heating } \\
\text { floor } \\
\text { area }\left(\mathrm{m}^{2}\right)\end{array}$} & \multicolumn{3}{|c|}{ Heating energy } & \multicolumn{2}{|c|}{ Electricity } & \multirow{2}{*}{$\begin{array}{c}\text { Total } \\
\text { Total } \\
\text { energy } \\
\left(\mathrm{kWh} / \mathrm{m}^{2}\right.\end{array}$} \\
\hline & & & $\begin{array}{l}\text { Oil cost } \\
\text { (Euro) }\end{array}$ & $\begin{array}{c}\text { Oil } \\
\text { quantity } \\
(\mathrm{kg})\end{array}$ & $\begin{array}{c}\text { Heating } \\
\text { energy } \\
\left(\mathrm{kWh} / \mathrm{m}^{2}\right)\end{array}$ & $\begin{array}{l}\text { Cost } \\
\text { (Euro) }\end{array}$ & $\begin{array}{c}\text { Consumptior } \\
\left(k W h / m^{2}\right)\end{array}$ & \\
\hline 1 & 44 & 2.048 .62 & $T$ & $13,524.84$ & 78.69 & 2,510 & 12 & 91.59 \\
\hline 2 & 1976 & 2,300 & 7,420 & $14,605.08$ & 75.69 & 1,724 & 7.89 & 83.58 \\
\hline 3 & & 2,214 & & $9,746.52$ & 52.47 & 1,809 & 8.60 & 61.07 \\
\hline 4 & $\begin{array}{l}1978 / \\
1992\end{array}$ & $3,089.6^{*}$ & 60 & $12,437.04$ & 78.72 & 4,339 & 14.78 & 93.50 \\
\hline 5 & 1980 & 902.23 & 4,761 & $9,476.04$ & 125.19 & 975 & 11.38 & 136.57 \\
\hline 6 & 1986 & 809 & 2,826 & $5,765.76$ & 85.00 & 649 & 8.45 & 93.45 \\
\hline 7 & 1990 & $2,745.54$ & 6,318 & $12,588.24$ & 54.65 & 2,250 & 8.63 & 63.28 \\
\hline 8 & 1992 & $1,613.15$ & 4,008 & $7,847.28$ & 57.99 & 1,720 & 11.22 & 69.21 \\
\hline 9 & 1996 & $2,398.5$ & 5,414 & $10,887.24$ & 54.11 & 2,023 & 8.88 & 62.99 \\
\hline 10 & $1957 / 1995$ & $2,348.96$ & 5,350 & 11,340 & 57.55 & 1,928 & 8.64 & 66.19 \\
\hline & & Total Mea & Consum & on: & 72.00 & & 10.14 & 82.14 \\
\hline
\end{tabular}

$* 1,883.15(1978)+1,206.45(1992)=3,089.6 \mathrm{~m}^{2}$

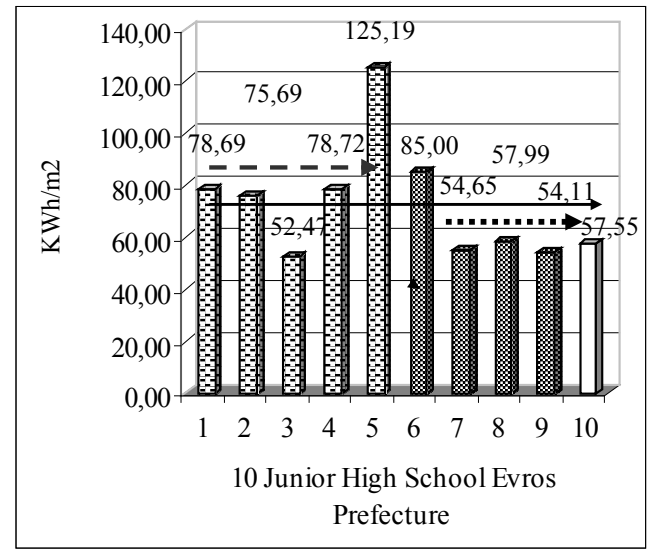

Fig. 1: Mean heating energy consumption in a sample of 10 junior high schools in the Prefecture of Evros for the period 2001-05

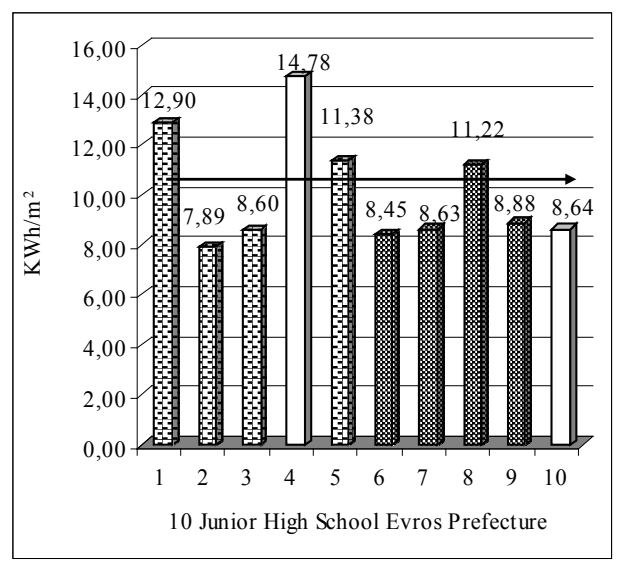

Fig. 2: Mean electrical energy consumption in a sample of 10 junior high schools in the Prefecture of Evros for the period 2001-05

Mean heating energy consumption for:

non - insulated junior high schools $(1,2,3,4,5)$ :

$82.16 \mathrm{kWh} / \mathrm{m}^{2}$ insulated junior high schools $(6,7,8,9)$ :

"Old" with "New" additions in junior high schools $(4,10)$ : $57.55 \mathrm{kWh} / \mathrm{m}^{2}$ All junior high schools 
The monitored energy consumption data, based on data of 5 years for the period 2001-2005, together with the construction year are summarized at tables 3 and 4 for the junior high schools and high schools respectively. The annual records for heating costs were available in each school and these values were quantified into energy consumption (in $\mathrm{kWh} / \mathrm{m}^{2}$ ) based on the mean annual price of diesel oil from the records of the Ministry of Development.

It is observed from figure 1 that the heating energy consumption in junior high schools ranges from $52.47 \mathrm{kWh} / \mathrm{m}^{2}$ up to $125.19 \mathrm{kWh} / \mathrm{m}^{2}$, with a mean value of $72 \mathrm{kWh} / \mathrm{m}^{2}$, showing the higher values in 'old' buildings. Building 10 concerns an old building with an addition and its energy consumption is in the levels of the "new' buildings. Junior high school no 4 is "old" with "new" additions, but the heating energy consumption concerns only the 'old' buildings while the electricity energy consumption both of them.

Table 4: Total mean energy consumption in 10 high schools of the Prefecture of Evros (2001-05)

\begin{tabular}{|c|c|c|c|c|c|c|c|c|}
\hline & & & \multicolumn{3}{|c|}{ Heating energy } & \multicolumn{2}{|c|}{ Electricity } & Total \\
\hline No & $\begin{array}{c}\text { Constru } \\
\text { ction } \\
\text { year }\end{array}$ & $\begin{array}{c}\text { Heating } \\
\text { floor area } \\
\left(\mathrm{m}^{2}\right)\end{array}$ & $\begin{array}{l}\text { Oil cost } \\
\text { (Euro) }\end{array}$ & $\begin{array}{c}\text { Oil quantity } \\
(\mathrm{Kg})\end{array}$ & $\begin{array}{c}\text { Heating } \\
\text { energy } \\
\left(\mathrm{kWh} / \mathrm{m}^{2}\right)\end{array}$ & $\begin{array}{c}\text { Cost } \\
\text { (Euro) }\end{array}$ & $\begin{array}{l}\text { Consumptior } \\
\left(\mathrm{kWh} / \mathrm{m}^{2}\right)\end{array}$ & $\begin{array}{c}\text { Total } \\
\text { energy } \\
\left(\mathrm{kWh} / \mathrm{m}^{2}\right.\end{array}$ \\
\hline 1 & 1970 & 3,300 & 10,828 & $21,215.04$ & 76.63 & 4,104 & 13.09 & 89.72 \\
\hline 2 & 1976 & 2,100 & 6,091 & $12,122.88$ & 68.81 & 2,126 & 10.66 & 79.47 \\
\hline 3 & 1976 & 4,405 & 20,103 & $40,057.92$ & 108.39 & 7,032 & 16.8 & 125.19 \\
\hline 4 & 1977 & 2,030 & 7,917 & $16,136.40$ & 94.75 & 2,547 & 13.21 & 107.96 \\
\hline 5 & 1981 & 3,500 & 18,799 & $39,170.88$ & 133.4 & 6,595 & 19.83 & 153.23 \\
\hline 6 & 1984 & 1,377 & 5,866 & $11,103.96$ & 96.12 & 1,222 & 9.34 & 105.46 \\
\hline 7 & 1985 & 2,716 & 7,768 & $15,333.36$ & 67.3 & 2,969 & 11.51 & 78.81 \\
\hline 8 & 1987 & $2,067.5$ & 4,057 & $7,866.60$ & 45.35 & 3,095 & 15.76 & 61.11 \\
\hline 9 & 1996 & 1,404 & 3,609 & $7,203.84$ & 61.16 & 2,009 & 15.06 & 76.22 \\
\hline 10 & 1999 & $2,398 ., 5$ & 6,646 & $12,701.64$ & 63.12 & 3,523 & 15.46 & 78.58 \\
\hline & & Total Mean & Consumpti & & 81.50 & & 14.10 & 95.60 \\
\hline
\end{tabular}

Concerning high schools (fig 3), the heating energy consumption ranges from $45.35 \mathrm{kWh} / \mathrm{m}^{2}$ up to $133.40 \mathrm{kWh} / \mathrm{m}^{2}$ with a mean value of $81.5 \mathrm{kWh} / \mathrm{m}^{2}$, showing the higher values in 'old' buildings. Energy consumption in units no 3 and 5 is increased (table 4 and fig. 3 кal 4) as they concern technical high schools, which are equipped with different laboratories (mechanical, computers, horticulture sunspaces, etc), resulting at high energy consumption.

The mean electrical energy consumption is $10.14 \mathrm{kWh} / \mathrm{m}^{2}$ in junior high schools 14.10 $\mathrm{kWh} / \mathrm{m}^{2}$ in high schools (tables 3 and 4) and $8.56 \mathrm{kWh} / \mathrm{m}^{2}$ in primary schools in the prefecture of Evros [4]. The electrical energy corresponds only to about the $1 / 6^{\text {th }}$ of the heating energy (fig. 5 and 6), mainly in the 'old' buildings', while in the new 'ones', electrical energy has a higher merit at the overall energy balance as the heating energy is reduced due to the improved building construction. 


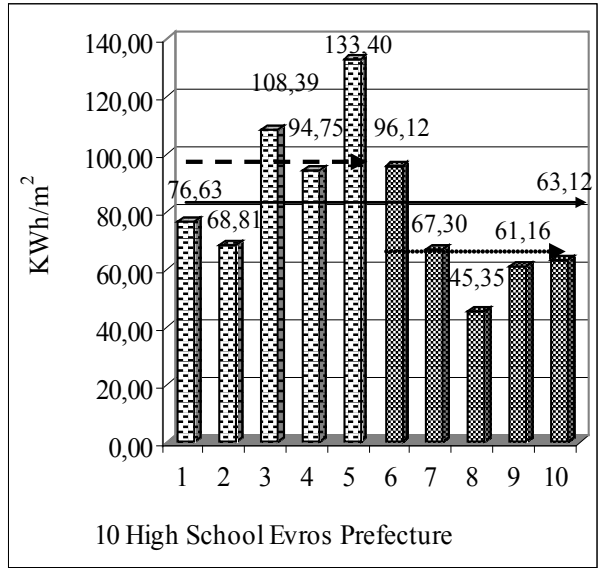

Fig. 3: Mean heating energy consumption in a sample of 10 high schools in the Prefecture of Evros for the period 2001-05

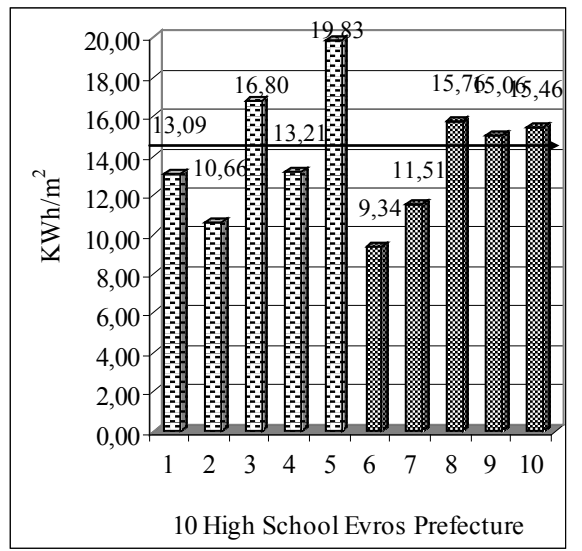

Fig. 4: Mean electrical energy consumption in a sample of 10 high schools in the Prefecture of Evros for the period 2001-05

Mean heating energy consumption for:

non-insulated high schools $(1,2,3,4,5)$ : insulated high schools $(6,7,8,9,10)$ : All high schools

\section{$96.40 \mathrm{kWh} / \mathrm{m}^{2}$ $66.61 \mathrm{kWh} / \mathrm{m}^{2}$ $81.50 \mathrm{kWh} / \mathrm{m}^{2}$}

The mean heating energy of the school units in the region (Climatic zone C) corresponds at the $85 \%-88 \%$ of the total energy consumption, compared to $72 \%$ that was recorded from previous studies [1] for all grades school buildings around Greece. This may attributed at the low temperatures recorded at this climatic zone and consequently the increased heating needs of the buildings, at the old age of buildings and lack of envelope insulation, at the fact that existing insulation in some buildings may be deteriorated, at the inadequate maintenance of the envelope and of the mechanical installations.

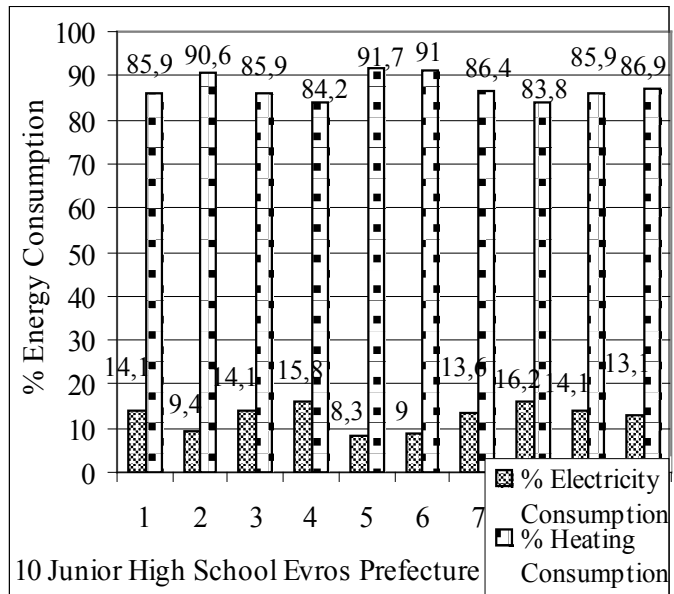

Fig.5: Mean energy consumption for heating and electricity (in \%) in junior high schools in the Prefecture of Evros

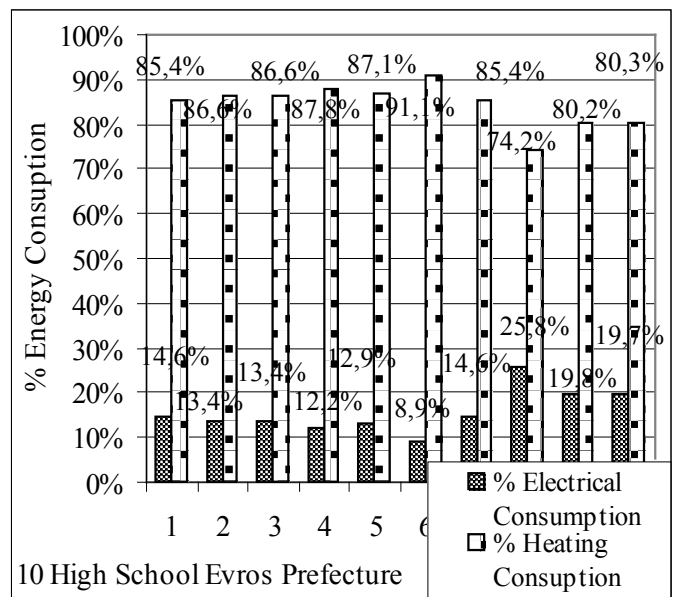

Fig. 6: Mean energy consumption for heating and electricity (in \%) in high schools in the Prefecture of Evros

Analyzing the energy performance of all secondary school buildings in the prefecture of Evros (climate zone C) (fig. 7) the mean heating energy consumption is $70.6 \mathrm{kWh} / \mathrm{m}^{2}$, with insulated buildings ('new') performing with $27 \%$ less energy consumption than non-insulated ('old') buildings. The $100 \%$ of insulated buildings show an energy consumption less than 100 
$\mathrm{kWh} / \mathrm{m}^{2}$, compared to $70 \%$ of the non-insulated ones (table $3 \& 4$ ). In an older study of 180 insulated and 58 non-insulated school buildings in different climatic zones [1], the heating energy consumption differs between them by $40 \%$, while the $88 \%$ of insulated buildings have energy consumption lower than $100 \mathrm{k} \mathrm{Wh} / \mathrm{m}^{2}$ compared to $79 \%$ of the 'non-insulated' buildings [1].

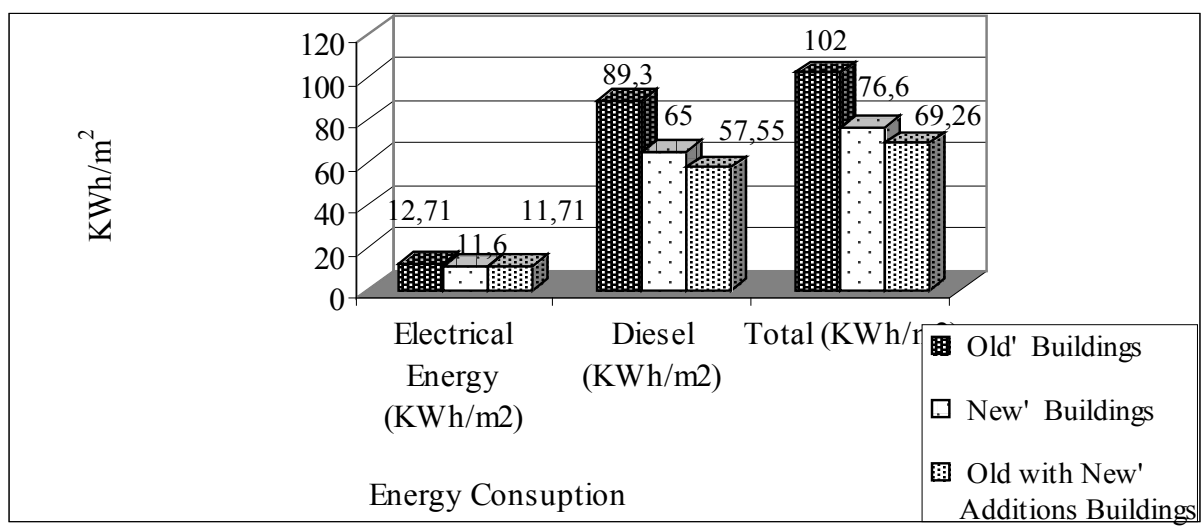

Fig. 7: Mean energy consumption according to the antiquity of 20 sschool buildings

\section{Assessment of the thermal performance of 6 school buildings}

For the thermal assessment of the school buildings, 6 units were chosen, 5 junior high schools and 1 hi gh school. The 4 junior high schools are located at the municipality of Alexandroupolis, representing $67 \%$ of junior high school buildings as well as the high school. From the 6 studied buildings, the 2 are 'old'ones constructed before 1981, and the 4 are 'new' ones, constructed after 1985. The thermal assessment of the studied school building and investigation of alternative energy saving measures was performed with the software tool XENIOS. The XENIOS is a European software tool that was developed in the frame of an Altener programme, partly financed by the EC DG on Energy and Transport. For each building the existing thermal performance was evaluated and alternative scenarios of energy upgrade were investigated.

\subsection{Conclusions from the thermal analysis}

\subsubsection{Heating period}

The following conclusions were drawn from the thermal analysis of the six buildings:

$>$ Replacement of the windows with new ones and improving their overall transmittance of windows from $5.2 \mathrm{~W} / \mathrm{m}^{2} \mathrm{~K}$ to $2.56 \mathrm{~W} / \mathrm{m}^{2} \mathrm{~K}$ in the 'old' buildings resulted at reduction of the energy requirements during the heating period by about $12 \%$. Improvement of the thermal properties of the windows in the 'new' buildings from $3.26 \mathrm{~W} / \mathrm{m}^{2} \mathrm{~K}$ to $2.56 \mathrm{~W} / \mathrm{m}^{2} \mathrm{~K}$ results at reduction from $1 \%$ up to $3 \%$.

$>$ Insulation of the external walls results at reduction of the energy consumption up to $12 \%$.

$>$ Insulation of the building envelope, with addition of insulation at the external walls, roof and windows replacement has an energy reduction up to $25 \%$ in 'old' buildings. In the 'new' ones a small energy reduction, in the order of $2 \%$ to $3 \%$ was observed.

$>$ In most school buildings, the heating system is oversized, not well maintained and in the majority, there is no provision for control of their operation [12, p.25]. Improvement of the efficiency of the boiler up to $90 \%$ may bring energy savings up to $27 \%$ in all school buildings. $>$ Improvement of the efficiency of the distribution system, with appropriate pipes insulation, especially in they case they pass through unheated spaces, may bring considerable energy reduction, up to $15 \%$ in the studied buildings. 
Control of the indoor air temperature with thermostats in classrooms may lead to energy reduction up to $21 \%$ in all studied buildings. Installation of time-controllers, low control, room temperature sensors or external temperature based controllers or more advanced control systems (e.g. optimizers) achieving synchronization of the external and internal climatic conditions with the operation of the heating system can achieve indoor thermal comfort and energy savings. A thermostatic valve in the heating system is considered necessary for achieving the desired temperature in a space and achieving energy savings.

$>$ The combined measures of improvement of the efficiency of the boiler and the distribution system and of the control of the indoor thermal conditions can increase the energy savings up to $52 \%$ both in the 'old' and the 'new' ones. Taking into account that in most school buildings, the heating system operates for a few hours, manually, with no room air temperature control, irrespective of indoor thermal conditions and outside climatic conditions and considering that the payback period for the improvement of the boiler and the distribution system efficiency is relatively low, it is considered imperative the replacement of the old systems with new ones.

Applying all the proposed measures in the studied school buildings, an energy reduction from $53 \%$ up to $64 \%$ may be achieved.

\subsubsection{Cooling period}

$>$ Insulation of the walls and of the roof would reduce energy cooling demands in 'old' buildings by about $2 \%$ in each case separately.

$>$ Painting the outside surface of the external walls with a light colour reduces by $5 \%$ and by $3 \%$ the energy demand in cooling loads in the "old" buildings while in the "new" buildings only by $1 \%$. The light colour on the roofs does not show a remarkable change in their thermal performance.

$>$ The installation of interior blinds on all openings of the buildings, especially of southern, eastern and western orientation, may conserve energy of up to $61 \%$.

$>$ Installation of ceiling fans in the centre of each classroom, of power 100-200W, is sufficient to create the conditions for thermal comfort, provided that is combined with adequate shading and natural ventilation [12, p.30]. It may result in conservation of cooling energy up to $100 \%$ when combined with shading devices and light colored roof and walls. This is due to the fact that while the limit of thermal comfort in a natural cooled space is $27^{\circ} \mathrm{C}$, when a fan operates, the heat is dispersed because of air currents and the comfort level is raised over $29^{\circ} \mathrm{C}$.

$>$ Also noctumal ventilation in schools is very effective especially during the hot days where the daily ventilation heats the building. It stores coolness in the thermal mass of the building, thereby reducing the thermal burden of the building during the next day. Schools are kept safe all night, so night ventilation can be applied without any risk.

$>$ Energy conservation with implementation of all scenarios can reach up to $100 \%$. At the same time, thermal comfort conditions are created in the classrooms that are considered necessary for the educational process and also contribute to reduction of air pollution with a lot of environmental and social benefits.

\section{Conclusions}

To ensure the efficient function of a school building and the reduction of problems that usually arise with time and the use of systems, the proper and regular maintenance of the building and its systems is essential. Collection and analysis of their energy data is essential for monitoring their energy performance and to react by taking the appropriate energy saving measures. In a national context, collection of energy data for different building categories can create reliable databases for certification of buildings and for prioritizing energy policy 
measures. The assessment of the thermal performance of the school buildings in this study may provide useful conclusions for the actions to be considered in school building of the C' climatic zone in order to improve energy efficiency and achieve comfort conditions in the working space. Actions like planning and monitoring of an energy management plan, maintenance of the electromechanical installation and regulation procedures of natural lighting, reduction of losses from air infiltration, controlled ventilation for the winter period, shading and natural ventilation for the period of cooling and interventions in the exterior building structure particularly in the "old" school buildings are required, both to achieve thermal comfort and conservation of energy.

\section{References}

[1] M. Santamouris, C.A. Balaras, E. Dascalaki, A. Argiriou, A. Gaglia, Energy Consumption and the potential for energy conservation in school buildings in Hellas, Energy 19(6), 1994, pp 653-660.

[2] B. Koulaidis, Mapping of the educational system in school buildings, Athens, Educational Research Centre, 2005.

[3] M. Santamouris, G. Mihalakakou, P. Patargias, N. Gaitani, K. Sfakianaki, M. Papaglastra, C. Pavlou, P. Doukas, E. Primikiri, V. Geros, M.N. Assimakopoulos, R. Mitoula, S. Zerefos, Using intelligent clustering techniques to classify the energy performance of school buildings, Energy and Buildings 39, 2007, pp. 45-51.

[4] F. Vagi, A. Dimoudi, Investigation of energy and comfort conditions in Greek primary schools, Proceedings of the $3^{\text {rd }}$ international Conference on P assive and Low Energy Cooling for the Built Environment, PALENC 2010 \& EPIC $2010 \& 1^{\text {st }}$ Cool Roof Conf., Rhodes, 29 Sept. - 2 October 2010.

[5] A. Dimoudi, P. Kostarela, Energy monitoring and conservation potential in school buildings in the climatic zone of Greece, Renewable Energy 34, 2008, pp. 289-296.

[6] T.G. Theodosiou, K.T. Ordoumpozanis, Energy comfort and indoor air quality in nursery and elementary school buildings in the climatic zone of Greece, Energy and Buildings 40(3), 2008, pp. 2207-2214.

[7] Energy, European Communities, New Solutions in Energy Utilisation; The guide to sustainable energy technologies for school, European Communities, 2000.

[8] O. Hernandex, K. Burke, O. Lewis, Development of energy performance benchmarks and building energy ratings for non-domestic buildings: an example for Irish primary schools, Energy and Buildings 40(1), 2008, pp. 249-254.

[9] S.P. Corgnati, V. Corrado, M. Filippi, A method for heating consumption assessment in existing buildings: A field survey concerning 120 Italian schools, Energy and Buildings 40(1), 2008, pp. 801-809.

[10] V. Butala, P. Novac, Energy consumption and potential energy savings in old school buildings, Energy and Buildings 29(3), 1999, pp. 241-246.

[11] CRES, Guidelines for Heating-Lighting Comfort and Saving Energy in Primary Schools, Athens, 1996.

[12] S. Yiannas, Environmental Assessment Methods-Environmental Targets and Architectural Programme", in the "Bioclimatic Design of Buildings and Surrounding Space”, Patra (Greece), Hellenic Open University, 2001, pp. 307-327. 